\title{
A preliminary investigation of ground beetle (Coleoptera: Carabidae) assemblages and vegetation community structure in Calluna vulgaris heathlands in NW Spain
}

\author{
David Cuesta, Angela Taboada, Leonor Calvo \& José M. Salgado
}

Cuesta, D., Taboada, A., Calvo, L. \& Salgado, J. M. 2006: A preliminary investigation of ground beetle (Coleoptera: Carabidae) assemblages and vegetation community structure in Calluna vulgaris heathlands in NW Spain. - Entomol. Fennica 17: 241-252.

We present results of a primary survey of carabid beetles in Calluna vulgaris heathlands in the Cantabrian mountain range, NW Spain. We selected four heathland sites and captured carabids during July-August 2004 by randomly placing 48 pitfall traps per site (192 traps in total). The mature heathland carabid assemblage was mostly characterised by generalist, open habitat species, brachypterous and medium-sized species. Several endemic species were also found. Dominant species were the same in the four heathland sites, but differences in the total number of species were due to rarely collected ones. Differences in carabid assemblage composition between heathland sites indicate that care should be taken when selecting a priori heathland replicates for future research. Results from this study are mainly exploratory, showing that there is a characteristic carabid assemblage for these mature heathlands, different from other shrub communities of the same area. Preservation of heathlands in a mature stage would require management practices to avoid its natural evolution to a degenerative phase and the possible disappearance of the adapted carabid species.

D. Cuesta, A. Taboada and J. M. Salgado, Department of Animal Biology, University of León, Campus de Vegazana s/n, E-24071 León, Spain; E-mail: dbadcs@unileon.es

L. Calvo, Department of Ecology, Genetics and Microbiology, University of León, Campus de Vegazana s/n, E-24071 León, Spain.

Received 12 December 2005, accepted 6 June 2006

\section{Introduction}

Heathlands dominated by Calluna vulgaris are recognised as a conservation priority by the European Union's Directive on Habitats and Species (European Commission 1992). This has contributed to an increase in the number of research studies focusing on this type of habitat as a conservation target. In the Cantabrian mountain range,
NW Spain, $C$. vulgaris heathlands are a scarce but characteristic vegetation community that represents the southern-most location of this type of heathland in Europe. Historically in this area heathlands have been subjected to management practices such as livestock (sheep, goats, cattle and horses) grazing in transhumance pastoral systems. Similarly to Western European areas, burning and cutting were regularly used to pro- 
vide pasture, contributing to maintain and increase the heathland extension (Aerts \& Heil 1993, Webb 1998). However, during the last decades traditional management has nearly disappeared due to changes in agricultural practices and socio-economical pressures, causing a progressive loss of heathland communities (Bobbink 1991, Marrs 1993, Pitcairn \& Fowler 1995). Consequently, heathlands characterised by $C$. vulgaris and other dwarf ericaceous species such as Erica tetralix are scarce in the Cantabrian mountain range today (Calvo et al. 2002). Indeed, as a result of the lack of management, the remaining heathland areas range from a mature to a degenerative state, probably affecting its regenerative potential when subjected to new disturbances (Mohamed \& Gimingham 1970, Berdowski \& Siepel 1988).

In general, $C$. vulgaris heathlands represent a man-made landscape (Usher 1992) characterised by a mosaic of different plant growth-phases each of them associated to specific insect communities (Gimingham 1985, Gardner 1991). The unusually high insect diversity (Kirby 1992, Usher 1992) of heathland depends on traditional management practices that contribute to the creation of small-scale mosaics of Calluna stands of different age and structure and that maximise insect diversity especially in case of carabid beetles (Usher 1992, Usher \& Thompson 1993, Gardner et al. 1997).

The majority of both dry and wet European heathlands have a distinctive and highly diverse carabid beetle fauna (e.g., Webb 1986, Gardner 1991, Usher 1992, Van Essen 1994, Gardner et al. 1997).

Carabid beetles are sensitive indicators of habitat alteration caused by management and land-use changes (Rainio \& Niemelä 2003, Purtauf et al. 2004, Vanbergen et al. 2005). While detailed information about carabid responses to forest and grassland management is available (e.g., Koivula 2002, du Bus de Warnaffe \& Lebrun 2004, Haysom et al. 2004, Grandchamp et al. 2005, Latty et al. 2006, Pihlaja et al. 2006, Taboada et al. 2006), very little is known about their responses to heathland management (Usher 1992, McFerran et al. 1995, Telfer \& Eversham 1996, Gardner et al. 1997). The lack of information is especially marked in the case of the effects on carabid beetles of recent changes in heathland traditional management practices and the appearance of heathland new disturbances, such as nitrogen deposition. This is the case of the Cantabrian Calluna heathlands.

In this paper we investigate the late summer carabid assemblage composition of $C$. vulgaris heathlands in the Cantabrian mountain range, NW Spain, where this type of landscape is threatened by the lack of management. There are several carabid faunistic and ecological studies developed in different shrub (i.e., Erica, Daboecia and Ulex species) communities of the same area (Vázquez 1990, Gutiérrez \& Menéndez 1997, Gutiérrez et al. 2004, Peláez 2004). But this exploratory study is the first specific work about carabid beetles in Calluna-dominated heathlands of the Iberian Peninsula, considered one of the richest areas both in total number of species and in endemic species in Europe (Serrano 2003). The two main constraints of this preliminary study were the specific heathland spatial configuration in the study area (i.e., with small size and patchy distributed fragments) and the short carabid activity period (i.e., mainly limited to June-September, free of snow) at high mountainous locations.

Our aim is to determine if there is a characteristic carabid beetle assemblage of this type of heathlands. We also aim to assess if variability in carabid assemblage composition exists between $a$ priori similar mature heathland ecosystems (i.e., belonging to the same growth-phase) and if this variability is related to the vegetation characteristics of each ecosystem. Vegetation characteristics (diversity, cover and structure) at either canopy or understorey layers have been found to affect the carabid assemblage composition (e.g., Gardner 1991, Gardner et al. 1997, Ings \& Hartley 1999, Jukes et al. 2001, Latty et al. 2006, Taboada et al. unpubl.). However, there is no general consensus on the scale and extend of vegetation effects on carabid beetles yet (see e.g., Koricheva et al. 2000, Brose 2003, Koivula et al. 2003, Thomas et al. 2006). Furthermore, this effects may be indirect and mediated by changes in environmental conditions (e.g., moisture, light, temperature), and may also be species-specific, i.e., affecting carabid individual species differently (Thomas et al. 2006). 


\section{Materials and methods}

\subsection{Study area}

The study area is situated in the Cantabrian mountain range, León, NW Spain, where Calluna vulgaris heathlands are scarce and patchy distributed. From a climatic viewpoint, this area has a Eurosiberian climate (Rivas-Martínez et al. 1987) characterised by the absence of a dry period in the warm season, the summer, or a dry period of less than two months. This area usually presents late snow that remains until the end of May. Mean annual precipitation is $1319.5 \mathrm{~mm}$ and the mean annual temperature is $+5.5^{\circ} \mathrm{C}$. Soils are podsols, although the underlying geology is different.

In this area, four $C$. vulgaris heathland sites (2-4 ha) were selected (i.e., four heathland independent replicates). These heathlands are classified as Luzulo henriquesii-Betuleto celtibericae communities (Penas et al. 1995), and were located at least $2.5 \mathrm{~km}$ apart: San Isidro (site A, 30TUN 3082 47694, 1620 m a.s.1.), Riopinos I (site B, 30TUN 3035 47687, $1660 \mathrm{~m}$ ), Riopinos II (site C, 30TUN 3007 47685, $1560 \mathrm{~m}$ ) and Vegarada (site D, 30TUN 2982 47682, $1560 \mathrm{~m}$ ). We considered these sites as mature heathland (sensu Watt 1955) as there are no records of recent burning or cutting practices for the last 40 years. Site A represents a flat and continuous heathland area, north facing, exposed to wind and close to a livestock grazing zone. Site B is characterised by a discontinuous heathland with high proportion of bare soil and north exposition in a marked slope. Site C is surrounded by a Genista shrubby area at the upper limit and by a livestock grazing area with a temporary stream at the lower limit. Site $\mathrm{C}$ is north facing and exposed to wind but with a less marked slope. Site D is the smallest heathland zone, represented by a mosaic of Calluna and Vaccinium areas and small pasture lands, located near a Genista shrubby area and surrounded by two permanent streams. Site D is south facing and exposed to wind with a slight slope.

\subsection{Sampling method}

We used plastic pitfall traps $(88 \mathrm{~mm}$ depth, $65 \mathrm{~mm}$ diameter) to collect the beetles, partly filled with $35 \%$ alcohol and detergent, and covered by $11 \times$ $11 \mathrm{~cm}$ roofs. We believe that alcohol $35 \%$ may have no relevant repellent/attractant effects on carabid beetles as only higher concentrations (i.e., 70\%) are expected to have a general attractant effect on insects (Woodcock 2005). The aim of adding a few drops of detergent into the pitfall traps is reducing surface tension, and increasing trap efficiency (Woodcock 2005). According to Pekár (2002), detergent as used here has no repellent/attractant effects on the carabid fauna (see also Woodcock 2005). Several carabid studies have used detergent added to a preservative solution to collect the beetles (e.g., Koivula et al. 2002, Taboada et al. 2004).

We randomly placed 48 traps per site and 192 traps in total. The average distance between traps was seven metres due to the small size and patchy distribution of the studied sites. However, distances between sampling points less than 25 metres imply that each trap cannot be considered an independent sampling unit (Digweed et al. 1995). Beetles were collected every 15 days during July and August 2004, identified using standard keys (Jeannel 1941-1942, Lindroth 1974, Trautner \& Geigenmüller 1987, Ortuño \& Mar$\cos 2003)$ and followed the nomenclature in Serrano (2003).

Vegetation sampling was carried out in July 2004. Four experimental plots $(10 \mathrm{~m} \times 20 \mathrm{~m})$ were placed in sites $\mathrm{A}, \mathrm{B}$ and $\mathrm{C}$. Two experimental plots $(10 \mathrm{~m} \times 20 \mathrm{~m})$ were placed in site $\mathrm{D}$, due to smaller extension of the Calluna heathland. In each plot ten vegetation sampling units of $1 \mathrm{~m}^{2}$ were randomly placed. A total of 40 sampling units were carried out in sites A, B and C, while 20 sampling units in site D. Percentage cover of each vascular plant species and bare soil was visually estimated in each sampling unit. The cover values of each vascular species were used to determine the life form cover: woody species, perennial and annual herbs. Plant nomenclature follows Tutin et al. (1964-1980). 
Table 1. Carabid beetles collected at the four heathland sites. Size $=$ carabid beetle body size range in $\mathrm{mm}$. Wings $(\mathrm{W})=$ wings morphology ( $b=$ brachypterous, micropterous or flightless, i.e., unable to fly; $m=$ macropterous; $D=\operatorname{dimorphic})$. Habitat $(H)=$ habitat association of the species ( $F=$ forest, $G=$ generalist and $O=$ open habitat species). Literature used: Jeannel (19411942), Lindroth (1974), Vázquez (1990), Campos (2003), Ortuño \& Marcos (2003) and Peláez (2004). Carabid beetle structural parameters are also indicated.

Heathland sites

Species

$\begin{array}{lllllllll}\text { Size } & \text { W } & \text { H } & \text { A } & \text { B } & \text { C } & \text { D } & \text { Total }\end{array}$

Amara (Amara) famelica Zimmermann, 1832

Bembidion (Bembidion) crassicorne Putzeys, 1878

Bembidion (Nepha) ibericum La Brûlerie, 1868

Bembidion (Metallina) lampros (Herbst, 1784)

Bradycellus (Bradycellus) verbasci

(Duftschmid, 1812)

Calathus (Neocalathus) asturiensis Vuillefroy, 1866

Calathus (Calathus) fuscipes graecus Dejean, 1831

Calathus (Neocalathus) melanocephalus

melanocephalus (Linnaeus, 1758)

Calathus (Calathus) uniseriatus Vuillefroy, 1866

Carabus (Oreocarabus) amplipennis getschmanni Lapouge, 1924

Carabus (Eucarabus) deyrollei Gory, 1839

Carabus (Chrysocarabus) lineatus lineatus Dejean, 1826

Carabus (Mesocarabus) macrocephalus macrocephalus Dejean, 1826

Cicindela (Cicindela) campestris campestris Linnaeus, 1758

Cicindela (Cicindela) sylvatica reiseri Mandl, 1970

Cryobius cantabricus cantabricus (Schaufuss, 1862)

Cymindis (Cymindis) coadunata kricheldorffi Puel, 1935

Cymindis (Cymindis) humeralis (Geoffroy, 1785)

Harpalus (Typsiharpalus) bonvouloiri Vuillefroy, 1866

Harpalus (Harpalus) latus (Linnaeus, 1758)

Harpalus (Harpalus) rubripes (Duftschmid, 1812)

Harpalus (Harpalus) rufipalpis rufipalpis Sturm, 1818

Laemostenus (Pristonychus) terricola terricola (Herbst, 1783)

Leistus (Leistus) nitidus (Duftschmid, 1812)

Licinus (Licinus) aequatus angustus Chevrolat, 1840

Nebria (Nebria) asturiensis Bruneau de Miré, 1964

Notiophilus biguttatus (Fabricius, 1779)

Olisthopus fuscatus Dejean, 1828

Poecilus (Poecilus) versicolor (Sturm, 1824)

Pterostichus (Oreophilus) cantaber (Chaudoir, 1868)

Synuchus vivalis vivalis (Illiger, 1798)

Trechus (Trechus) fulvus fulvus Dejean, 1831

Trechus (Trechus) quadristriatus (Schrank, 1781)

Zabrus (Iberozabrus) consanguineus Chevrolat, 1865

Number of individuals

Number of species

Exclusive species

Evenness

Diversity index

\begin{tabular}{|c|c|c|c|c|c|c|}
\hline $6.6-9.0$ & $\mathrm{~m}$ & $\mathrm{O}$ & - & - & - & 3 \\
\hline $2.5-3.0$ & $b$ & $\mathrm{O}$ & - & - & - & 5 \\
\hline $3.0-4.0$ & $\mathrm{~m}$ & $\mathrm{O}$ & - & 1 & - & - \\
\hline $2.5-4.0$ & D & G & 1 & - & 2 & 14 \\
\hline $3.5-4.0$ & $\mathrm{~m}$ & G & 5 & 6 & 2 & - \\
\hline $8.0-12.0$ & D & O & 21 & 233 & 44 & 3 \\
\hline $10.0-15.0$ & $\mathrm{~b}$ & G & - & - & - & 1 \\
\hline $6.0-8.0$ & D & O & 2 & - & - & - \\
\hline $9.5-13.0$ & $b$ & O & 1 & 17 & - & - \\
\hline $18.0-22.0$ & $b$ & G & - & 1 & - & 12 \\
\hline $14.0-18.0$ & $b$ & G & - & 2 & - & 1 \\
\hline $24.0-32.0$ & $b$ & G & - & - & 3 & 3 \\
\hline $25.0-30.0$ & $b$ & G & 1 & 2 & 9 & 31 \\
\hline $12.0-15.0$ & $\mathrm{~m}$ & 0 & - & 1 & - & _- \\
\hline $15.0-19.0$ & $\mathrm{~m}$ & G & - & 1 & - & - \\
\hline $7.5-8.0$ & $b$ & $\mathrm{~F}$ & 53 & 26 & 91 & 57 \\
\hline $8.0-10.0$ & $b$ & $\mathrm{O}$ & - & - & - & 1 \\
\hline $8.0-11.0$ & $b$ & $\mathrm{O}$ & - & 2 & - & - \\
\hline $11.0-11.5$ & $\mathrm{~m}$ & G & - & - & - & 1 \\
\hline $8.0-11.0$ & $\mathrm{~m}$ & G & - & - & - & 1 \\
\hline $8.0-10.0$ & $\mathrm{~m}$ & 0 & 1 & - & - & - \\
\hline $7.0-9.0$ & $\mathrm{~m}$ & $\mathrm{O}$ & - & 2 & - & - \\
\hline $10.0-18.0$ & $b$ & G & - & 2 & - & - \\
\hline $7.5-9.0$ & $\mathrm{~b}$ & $\mathrm{~F}$ & 1 & - & - & - \\
\hline $11.0-14.0$ & $b$ & G & - & - & - & 2 \\
\hline $10.5-13.5$ & $b$ & $\mathrm{~F}$ & 1 & 3 & - & - \\
\hline $5.0-5.5$ & D & $\mathrm{F}$ & 5 & - & 16 & 13 \\
\hline $5.0-7.0$ & $b$ & 0 & 2 & - & - & - \\
\hline $11.0-13.0$ & $\mathrm{~m}$ & 0 & - & - & - & 10 \\
\hline $13.0-16.0$ & $b$ & $\mathrm{~F}$ & 1 & 3 & - & 18 \\
\hline $7.0-9.0$ & $\mathrm{~m}$ & G & 1 & 24 & 2 & 15 \\
\hline $4.8-5.8$ & $b$ & G & - & - & 1 & - \\
\hline $3.2-4.0$ & $\mathrm{~m}$ & G & 2 & - & - & - \\
\hline \multirow[t]{6}{*}{$13.5-15.5$} & $b$ & $\mathrm{O}$ & - & 3 & - & - \\
\hline & & & 98 & 329 & 170 & 191 \\
\hline & & & 15 & 17 & 9 & 18 \\
\hline & & & 5 & 7 & 1 & 8 \\
\hline & & & 0.58 & 0.43 & 0.60 & 0.78 \\
\hline & & & 2.28 & 1.75 & 1.91 & 3.26 \\
\hline
\end{tabular}




\subsection{Data analysis}

Pitfall catches reflect carabid activity-density, i.e., both the movement behaviour and abundances of the beetles (e.g., Thomas et al. 1998, 2006) that will be referred to here as abundance or number of individuals. Carabid abundance data from each site and for the whole trapping period were pooled, and the species were classified according to the literature as forest specialist, generalist or open habitat species (Table 1). Carabid species were also grouped according to morphological characteristics: body size (ranges: 0-4.9, 5-9.9, 10-14.9, 15-19.9 and $>20 \mathrm{~mm}$ ) and wings $(b=$ brachypterous, micropterous or flightless (i.e., unable to fly); $\mathrm{m}=$ macropterous; $\mathrm{D}=$ dimorphic) (Table 1). We performed one-way ANOVA analyses to test for significant differences in carabid beetle habitat association (i.e., forest specialist, generalist and open habitat species) and wings morphology (i.e., flightless, macropterous and dimorphic) among the four heathland sites. Scheffe post-hoc tests were performed to determine the statistical significance of the differences. The analyses were carried out using Statistical Program for the Social Sciences 11.5 (SPSS Inc. 1989-2002).

We performed a Detrended Correspondence Analysis (DCA) as a summarising technique to correlate carabid species and heathland sites (Jongman et al. 1995) using the R package (R Development Core Team 2005). Likewise, Canonical Correspondence Analysis (CCA) was used to detect the main relations between carabids and the environment characteristics (CANOCO, Ter Braak 1987, Ter Braak \& Smilauer 1998). Environmental variables used in the CCA were: cover of Calluna vulgaris (Cavu), Erica tetralix (Erte), Vaccinium myrtillus (Vamy), annual herbaceous (AnHe), perennial herbaceous (PeHe), bare soil (Baso), and vegetation richness (Rich). Monte Carlo permutation test was applied to estimate the significance of the CCA.

Both multivariate analyses assume a unimodal response of the carabid abundances to the environment (Ter Braak and Smilauer 1998). Carabid abundance data were log-transformed $[\operatorname{Ln}(\mathrm{x}+1)]$ for ordination and canonical ordination analyses to give less weight to dominant species (Jongman et al. 1995). All carabid species were included in these analyses. Vegetation cover data were arcsine-square root transformed [arcsine Root $(\mathrm{x} / 100)$ ] for canonical ordination analysis.

Carabid and vegetation data were used to determine diversity $\left(\mathrm{H}^{\prime}=\right.$ Shannon Index; Shannon \& Weaver 1949) and its two components: richness $(\mathrm{S}=$ number of species $)$ and evenness $\left(\mathrm{J}^{\prime}=\right.$ H'/H'max). Life form (woody species, annual and perennial herbs), $C$. vulgaris, E. tetralix and bare soil cover were analysed by a one-way ANOVA in order to look for differences between sites. Vegetation and soil cover data were arcsinesquare root transformed before their inclusion in the analyses. Likewise, structural parameters (diversity, richness and evenness) were analysed using one-way ANOVA in order to look for differences between heathland sites. Scheffe post hoc tests were performed to determine the statistical significance of the differences. The analyses were carried out using Statistical Program for the Social Sciences 11.5 (SPSS Inc. 1989-2002).

\section{Results}

A total of 788 carabid individuals and 34 species were collected (Table 1). Site B sampled the highest abundance (329 individuals), mainly due to Calathus asturiensis (233 individuals), while site A presented the lowest (98 individuals). Species richness was similar at sites A, B and D $(15,17$ and 18 species, respectively), and higher than site C (9 species). Site D was characterised by the highest diversity value (diversity index $=3.26$ ) due to greatest values for both species richness and evenness (18 and 0.78 , respectively). On the other hand, site B was characterised by the lowest diversity value (diversity index $=1.75$ ) mainly because of a low evenness value (0.43), indicating the high dominance of $C$. asturiensis.

The carabid assemblage of heathland sites mainly consisted of generalist (44.1\% of the species) and open habitat specialist species $(41.2 \%)$, although not statistically significantly $\left(F_{2,9}=3.48\right.$; $p=0.08)$. Generalist species were evenly represented by species belonging to all body size ranges (Fig. 1a) and mainly by brachypterous species (i.e., dominant in both number of species and individuals, Fig. 1b). Open habitat specialist 


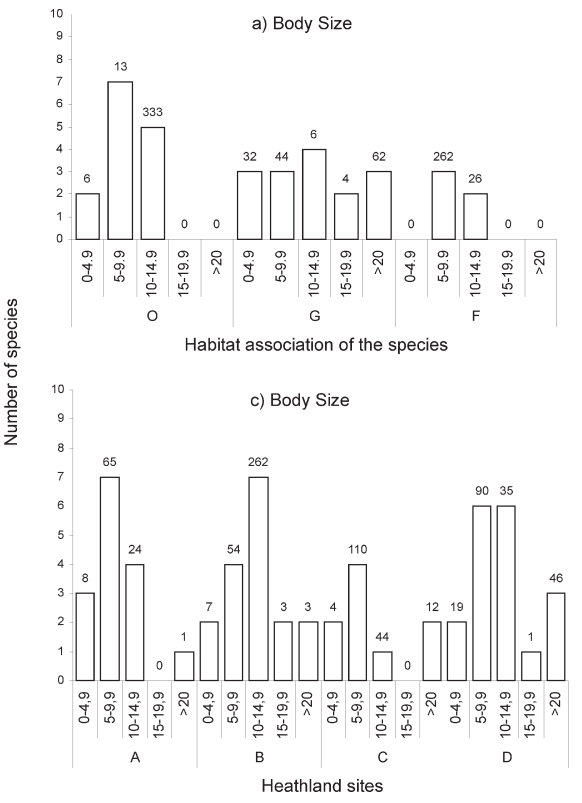

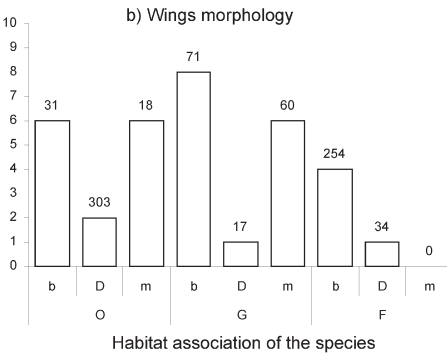

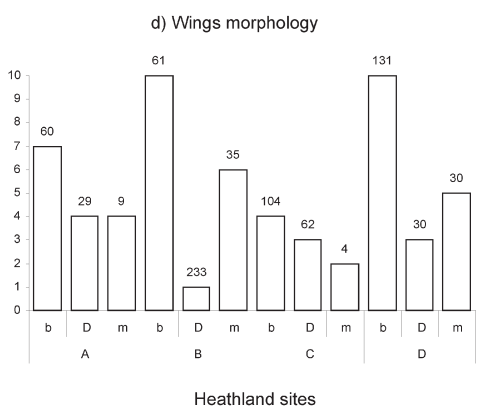

Fig. 1. Relation between carabid beetle morphological aspects - body size (ranges: 0 $4.9,5-9.9,10-14.9$, $15-19.9$ and $>20 \mathrm{~mm}$ ) and wing morphology ( $b=$ brachypterous, micropterous or flightless, i.e., unable to fly; $\mathrm{m}=$ macropterous; $\mathrm{D}=$ dimorphic) - with the habitat association of the species $(F=$ forest, $\mathrm{G}=$ generalist and $\mathrm{O}=$ open habitat species) and the four heathland sites (A, B, C, D). Number of individuals is indicated above each column. species were mostly represented by mediumsized species (i.e., dominant in both number of species and individuals, Fig. 1a) and by a high number of dimorphic individuals due to $C$. asturiensis (Fig. 1b). Forest specialist species were mainly represented by medium-sized and flightless species (Fig. 1a-b). The carabid assemblage of the Calluna heathland was statistically significantly characterised by a higher number of brachypterous species $\left(F_{2,9}=6.20 ; p=0.02\right)$ than the other two wings morphologies (Fig. 1c-d). Site B sampled a high number of dimorphic individuals due to $C$. asturiensis (Fig. 1d).

The most abundant species captured from all four heathland sites were: C. asturiensis (301 individuals, $38.2 \%$ of the total catch), Cryobius cantabricus (227 individuals, 28.8\%), Carabus macrocephalus (43 individuals, 5.5\%) and Synuchus vivalis (42 individuals, 5.3\%). Endemic species (C. asturiensis, C. cantabricus, Nebria asturiensis and Pterostichus cantaber) that are geographically restricted to this mountain range represented $70 \%$ (554 individuals) of the total catch (Table 1).

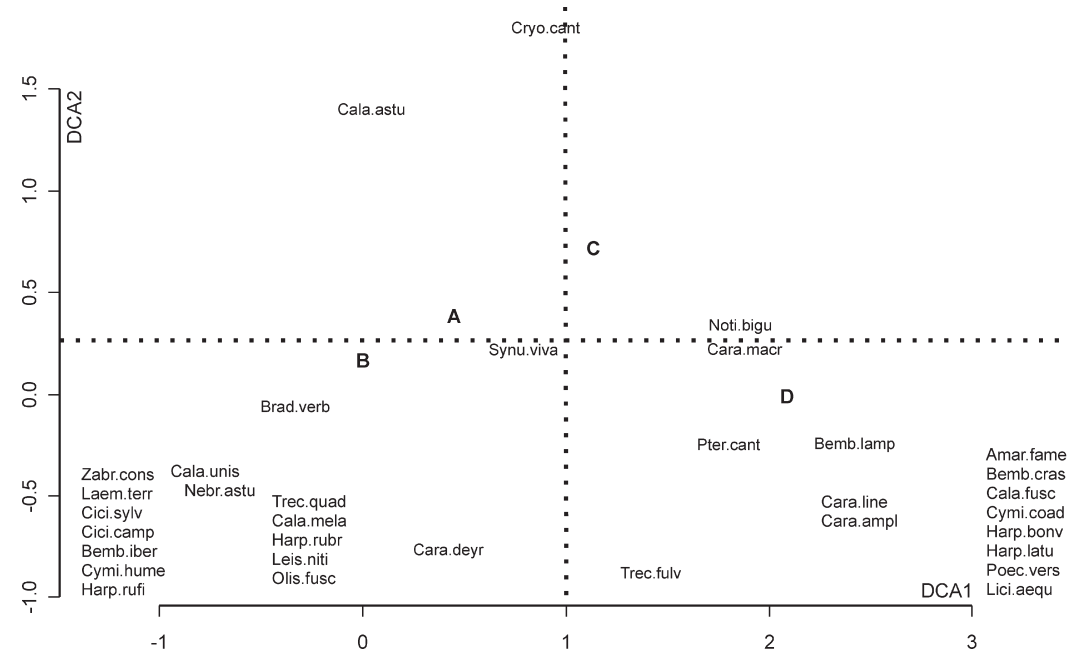

Fig. 2. Detrended Correspondence Analysis (DCA) (eigenvalues and axis lengths: 0.44 and 2.09 SD for axis 1 , 0.07 and $0.73 \mathrm{SD}$ for axis $2,0.09$ and 0.79 SD for axis 3 , and 0.10 and 0.82 SD for axis 4 , respectively) for carabid species and heathland sites (A, B, C, D). Carabid species names are a combination of 4 (genus name) by 4 (species name) letters. For example, Cala astu = Calathus asturiensis. 
Table 2. Vegetation characteristics of the four heathland sites. Mean ( \pm Standard Deviation) percentage cover of abundant shrub and herb species, bare soil, and woody, annual and perennial herbs. Vegetation structural parameters are also indicated.

Heathland sites

A

\section{Shrub species}

Calluna vulgaris

Chamaespartium tridentatum

Cytisus oromediterraneus

Erica australis

Erica tetralix

Juniperus communis

Ulex minor

Vacciniun myrtillus

Vacciniun uliginosum

Polygala microphylla

Herb species

Carex muricata

Deschampsia flexuosa

Festuca rubra

Hieracium pilosella

Jasione montana

Juncus squarrosus

Nardus stricta

Potentilla erecta

Woody plants

Annual herbs

Perennial herbs

Bare soil

Structural parameters

Gamma diversity

Species richness

Evenness

$\begin{array}{ll}65.7 \pm 4.1 & 67.9 \pm 5.0 \\ 0.2 \pm 0.31 & - \\ 0.3 \pm 0.4 & - \\ - & 5.5 \pm 8.3 \\ 24.1 \pm 16.2 & 0.2 \pm 0.5 \\ - & - \\ - & - \\ 14.6 \pm 5.3 & 2.7 \pm 3.2 \\ 4.4 \pm 6.1 & - \\ 0.2 \pm 0.4 & - \\ 1.1 \pm 1.3 & - \\ 2.6 \pm 0.8 & 0.6 \pm 1.2 \\ 0.7 \pm 1.1 & 0.5 \pm 0.6 \\ 0.1 \pm 0.2 & - \\ 0.5 \pm 0.9 & - \\ 2.9 \pm 3.2 & 0.3 \pm 0.5 \\ 5.1 \pm 0.9 & - \\ 1.3 \pm 1.2 & - \\ 109.5 \pm 13.9 & 75.1 \pm 1.9 \\ 0.5 \pm 0.9 & - \\ 17.1 \pm 4.7 & 1.3 \pm 2.3 \\ 51.2 \pm 5.4 & 60.2 \pm 3.4\end{array}$

$70.5 \pm 1.4$

$-$

$2.0 \pm 2.8$

$-$

$0.1 \pm 0.3$

$36.0 \pm 18.2$

$-$

$1.5 \pm 3.0$

$2.2 \pm 1.1$

$-$

$0.02 \pm 0.05$

$-$

$-$

$0.3 \pm 0.3$

$-$

$47.0 \pm 0.0$

$-$

$0.3 \pm 0.3$

$0.2 \pm 0.3$

$0.9 \pm 0.9$

$-$

$-$

$-$

$2.2 \pm 2.9$

$5.9 \pm 4.4$

$1.3 \pm 2.0$

$\overline{2} .9 \pm 0.9$

$2.4 \pm 2.0$

$5.0 \pm 2.1$

$1.4 \pm 1.3$

$-$

$2.0 \pm 1.6$

$7.3 \pm 0.4$

$106.8 \pm 12.3$

$116.5 \pm 16.3$

$6.5 \pm 0.9$

$10.6 \pm 8.5$

$38.9 \pm 5.6$

$21.2 \pm 8.8$

$\begin{array}{llll}2.3 & 0.8 & 1.7 & 2.8 \\ 23 & 7 & 15 & 26 \\ 0.5 & 0.3 & 0.5 & 0.6\end{array}$

Main differences among sites were due to rarely collected species: 21 species $(62 \%$ of the total catch) were exclusively captured from one site (Table 1). Site D showed the highest number of exclusive species ( 8 species) and site $C$ the lowest (only one species, Trechus fulvus). The DCA showed that the carabid assemblage composition of sites B and D clearly differed from the other two sites (Fig. 2) due to several scarce and exclusively collected species. Site D was characterised by abundant species such as Carabus lineatus, C. macrocephalus, C. amplipennis, Bembidion lampros, Poecilus versicolor and Pterostichus cantaber and by several rare species as indicated by the positive part of Axes I (Fig. 2). Site B was characterised by abundant species such as Bradycellus verbasci, Calathus uniseriatus and by several rare species as indicated by the negative part of Axes I (Fig. 2).

Regarding the vegetation characteristics, we found statistically significant differences among the study sites in total woody species cover $\left(F_{3,72}=43.88 ; p<0.05\right)$ (Table 2). However, in terms of individual shrub species, there were no significant differences among sites in the cover of the dominant and characteristic species in these heathlands, Calluna vulgaris (Table 2). Vaccinium myrtillus was another woody species that appeared in all four sites and presented the highest cover value at site $\mathrm{D}$ (Table 2 ).

There were significant differences among sites in both perennial $\left(F_{3,72}=104.36 ; p<0.05\right)$ and 


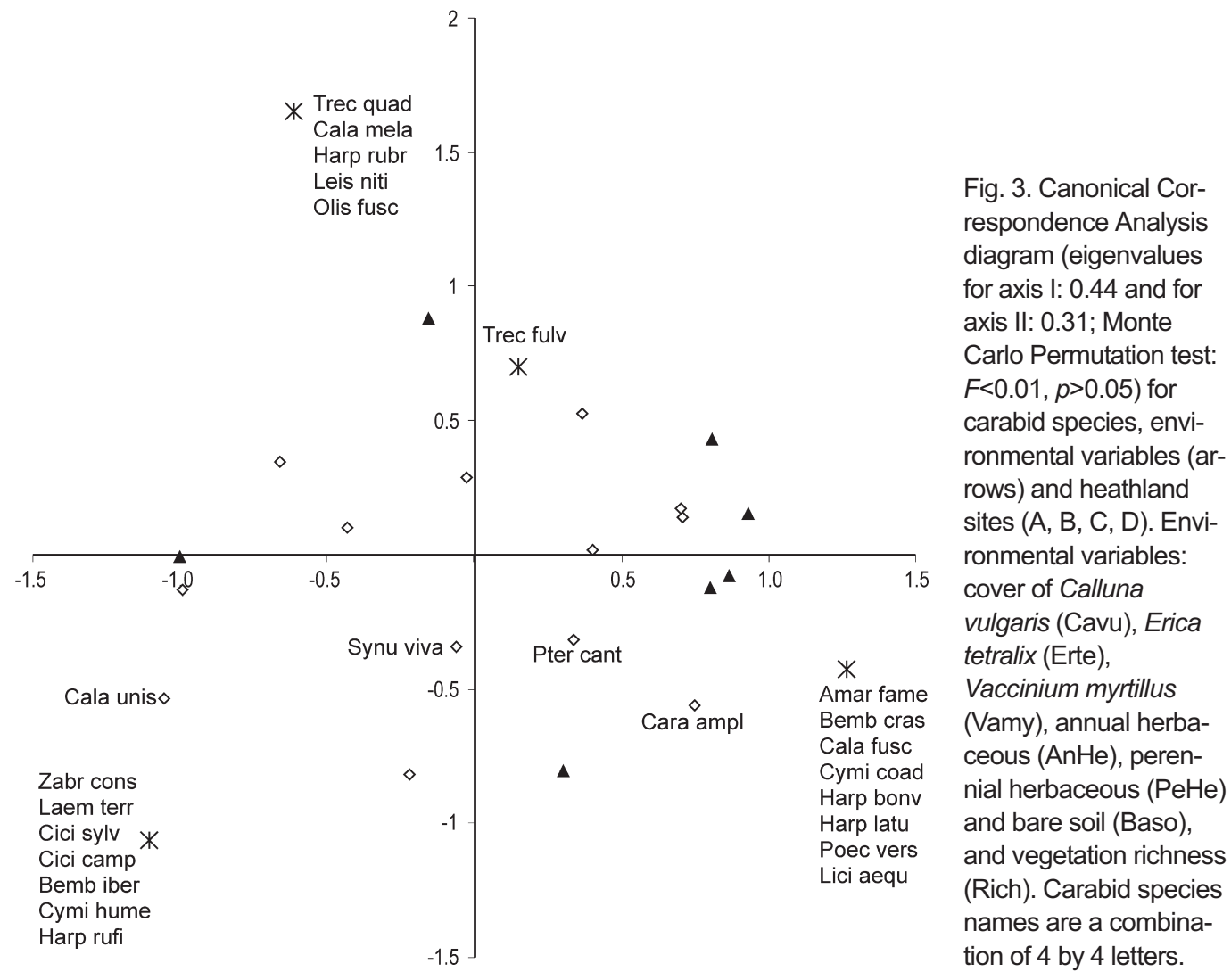

annual herbs $\left(F_{3,72}=3.22 ; p=0.044\right)$. Several graminoid perennial species presented high cover values such as Deschampsia flexuosa, Nardus stricta and Juncus squarrosus (Table 2). In general, site D was characterised by the highest values for the three life forms (woody, perennial and annual herbs), while site B was for the lowest (Table 2).

The vegetation structural parameters showed statistically significant differences among sites in both diversity $\left(F_{3,72}=68.57, p<0.05\right)$ and species richness $\left(F_{3,72}=57.28, p<0.05\right)$, with site D representing the highest values for both parameters and site B the lowest (Table 2). In terms of evenness, site B had the lowest value due to C. vulgaris dominance (Table 2).

Ordination of carabid species, environmental characteristics and heathland sites was defined by the two CCA first axes (Fig. 3). Eigenvalues for axis I and II were 0.44 and 0.31 , respectively. Ter
Braak (1987) considered that eigenvalues near 0.3 are normal values for ecological studies. The four heathland sites were differentiated by the environmental variables included in the CCA (Fig. 3). For example, site D was associated with the same carabid species as in the DCA (Fig. 2) and was correlated with great plant species richness and with high cover values for perennial herbaceous, annual herbaceous, V. myrtillus and $C$. vulgaris. On the other hand, site B, located in the negative part of axes I, was associated with high cover of bare soil and low values of plant richness. Sites A and $\mathrm{C}$ were mainly associated with high cover of Erica tetralix. Regarding the carabid fauna and the environment, several carabid species were associated to one or a few of the environmental variables included in the CCA analysis. For example, $C$. asturiensis and $N$. asturiensis were associated to high cover of bare soil (Fig. 3). 


\section{Discussion}

The mature Calluna vulgaris heathland studied had characteristic late summer carabid beetle assemblages as compared to other shrub communities of the Cantabrian mountain range (Vázquez 1990, Gutiérrez \& Menéndez 1997, Gutiérrez et al. 2004, Peláez 2004). The carabid assemblages of these heathlands were mainly characterised by open habitat specialist and generalist species, several abundant endemic species, and dominant brachypterous and medium-sized species. In terms of carabid beetles, representative species collected from all heathland sites included $\mathrm{Ca}$ lathus asturiensis, Carabus macrocephalus, Cryobius cantabricus and Synuchus vivalis. Regarding the vegetation species, $C$. vulgaris was confirmed as the dominant and characteristic shrub species of these heathland communities.

However, these results also indicated that $C$. vulgaris heathlands were heterogeneous to a certain degree, likewise to other shrub communities in the same mountain range (Luis-Calabuig et al. 2000, Calvo et al. 2005). Heterogeneity between heathland sites was found in terms of several exclusively collected carabid species, in terms of differences in the percentage cover of the vegetation life forms, and in both carabid beetle and vegetation structural parameters.

Abundantly collected carabid species were common to all four heathland sites, with differences among them being due to less common species, which is in accordance with Van Essen (1994). Therefore, the carabid assemblage structure of the C. vulgaris heathlands was characterised by a few very abundant species and many scarce species, with almost no intermediate ones as occurs in boreal forests (Niemelä 1993). Opposite results were found for Calluna-heathland areas in Britain, where the number of abundant and scarce species was similar (Gardner 1991, but see Van Essen 1994).

Several endemic species ( $C$. asturiensis, $C$. cantabricus, Nebria asturiensis and Pterostichus cantaber) that are geographically restricted to the Cantabrian mountain range were common to all heathland sites. C. asturiensis has also been found in dry and wet shrubland areas (Erica australis and E. arborea species in dry areas, and Daboecia cantabrica in wet ones) of similar open mountain sites (Vázquez 1990, Peláez 2004, Taboada et al. unpubl.). Likewise, C. cantabricus, $N$. asturiensis and $P$. cantaber, all forest specialist species, have been abundantly found in beech forests (Vázquez 1990, Peláez 2004, Taboada et al. 2004) and natural pinewoods (Taboada et al. unpubl.) in same geographical location. In case of $C$. cantabricus, the high abundances obtained in Calluna-dominated heathlands indicated its wide distribution in this mountain range.

At the carabid assemblage level, high vegetation structural complexity was directly related to a more diverse carabid beetle assemblage, similarly to heathlands in northeast England and Scotland (Gardner 1991, Usher 1992, Gardner et al. 1997). Indeed, site D represented the highest values for both carabid and vegetation structural parameters; meanwhile site B represented the lowest values. The highest number of carabid species sampled in site D is probably due to the smallest size of this heathland area. Less core habitat and great edge effects at site D may cause higher carabid species invasion from the surroundings (see Webb \& Hopkins 1984, Webb et al. 1984).

At the carabid species level, vegetation characteristics and structure at site $\mathrm{D}$, with high herb values and Vaccinium myrtillus cover (i.e., probably indicating more humidity) may positively influence the presence of a greater number of carabid species, such as Bembidion lampros, $C$. macrocephalus, C. cantabricus, $P$. cantaber and $S$. vivalis, among others. Site D was characterised by several large-sized carabid species, probably due to the protection offered by the denser and more complex vegetation community (Brose 2003). In case of site $B$, high percentage of bare soil and C. vulgaris cover, and low herb cover (i.e., contributing to create more homogeneous conditions) may positively influence the high number of individuals of $C$. asturiensis. Less dense vegetation (i.e., increased carabid movements) and high bare soil cover (i.e., high temperature at ground level) may affect pitfall trap efficiency favouring the high number of $C$. asturiensis collected here (see Raworth \& Choi 2001, Thomas et al. 2006). As pitfall trap catches reflect both movement behaviour and abundances of carabid beetles (i.e., activity-density), catches may have been influenced by different vegetation covers at the four heathland sites. Consequently, 
possible differences in trap efficiency between sites should be taken into account when interpreting the carabid beetle results obtained here (see e.g., Koivula et al. 2003).

To conclude, our results indicated that the mature stages of the $C$. vulgaris heathlands held a characteristic carabid assemblage in the Cantabrian mountain range. The preservation of this specific carabid assemblage is probably related to the maintenance of the mature phase of the heathland and its vegetation structure. The longterm maintenance of the heathland mature stage (i.e., not entering in a degenerate phase) requires traditional management practices such as burning and cutting (McFerran et al. 1995, Bartolomé et al. 2005) that are progressively disappearing in the study area. The reduction in heathland traditional management is likely to result in loss of the vegetation mosaic structure and will probably affect the adapted carabid species (Gardner et al. 1997).

Similarly, the effects of the vegetation entering in a degenerate phase, either due to the natural progression of the heathland or due to increased new disturbances (such as nitrogen atmospheric depositions), may affect the carabid assemblage composition. Transition from mature heathlands to degenerate ones may lead to subsequent changes in the dominance of the vegetation, with the substitution of $C$. vulgaris by graminoid herb species and bare soil areas (Aerts \& Heil 1993). Such changes in the vegetation structure may favour phytophagous and macropterous carabid species (such as Amara, Bradycellus and Harpalus species), more adapted to grassland areas with high seed production.

Finally, even small vegetation differences (i.e., reflecting distinct microhabitat conditions) between heathland sites may affect the carabid fauna and the reliability of a priori chosen heathland replicates. Therefore, results from this initial survey will be used to select new Callunadominated heathland areas for future research on the effects of experimental disturbances (e.g., burning and fertilizing) on carabid beetles. The ultimate goal will be to determine the effects of management and land use change on the beetles (Gardner et al. 1997), and to evaluate its conservation value. There is a need to develop specific insect conservation measures as botanically tar- geted measures do not appear to benefit heathland carabid assemblages (Telfer \& Eversham 1996).

Acknowledgements. We thank N. Pérez, E. Garrido, L. Collado, R. Tárrega and all the enthusiasts who helped with the fieldwork. We thank the Servicio Territorial de Medio Ambiente de la Junta de Castilla y León, who granted permission to work in heathlands. The study was supported by Ministerio de Ciencia y Tecnología (project reference REN2003-05432/GLO).

\section{References}

Aerts, R. \& Heil, G. W. 1993: Heathlands. Patterns and processes in a changing environment. - Kluwer Academic Publishers, Dordrecht. 223 pp.

Bartolomé, J., Plaixats, J., Fanlo, R. \& Boada, M. 2005: Conservation of isolated Atlantic heathlands in the Mediterranean region: effects of land-use changes in the Montseny biosphere reserve (Spain). — Biological Conservation 122: 81-88.

Berdowski, J. J. M. \& Siepel, H. 1988: Vegetative regeneration of Calluna vulgaris at different ages and fertilizer levels. - Biological Conservation 46: 85-93.

Bobbink, R. 1991: Effects of nutrient enrichment in Dutch chalk grassland. - Journal of Applied Ecology 28: $28-41$.

Brose, U. 2003: Bottom-up control of carabid beetle communities in early successional wetlands: mediated by vegetation structure or plant diversity? - Oecologia 135: 407-413.

Calvo, L., Tárrega, R. \& Luis, E. 2002: Regeneration patterns in a Calluna vulgaris heathland in the Cantabrian mountains (NW Spain): effects of burning, cutting and ploughing. - Acta Oecologia 23(2): 81-90.

Calvo, L., Alonso, I., Fernández, A. J. \& de Luis, E. 2005: Short term study of effects of fertilisation and cutting treatments on the vegetation dynamics of mountain heathlands in Spain. - Plant Ecology 179: 181-191.

Campos, A. M. 2003: Estudio de los Carabidae (Coleoptera) de Galicia. - PhD thesis, Universidad de Santiago de Compostela, Spain. 660 pp. [In Spanish.]

Digweed, S. C., Currie, C. R., Cárcamo, H. A. \& Spence J. R. 1995: Digging out the "digging-in effect" of pitfall traps: Influences of depletion and disturbance on catches of ground beetles. - Pedobiologia 39: 561576.

du Bus de Warnaffe, G. \& Lebrun, P. 2004: Effects of forest management on carabid beetles in Belgium: implications for biodiversity conservation. - Biological Conservation 118: 219-234.

European Commission 1992: Council Directive of 21 May 1992 on the Conservation of Natural Habitats and of Wild Fauna and Flora (92/43/EEC).

Gardner, S. M. 1991: Ground beetle (Coleoptera: Carabidae) communities on upland heath and their as- 
sociation with heathland flora. - Journal of Biogeography 18: 281-289.

Gardner, S. M., Hartley, S. E., Davies, A. \& Palmer, S. C. F. 1997: Carabid communities on heather moorlands in northeast Scotland: the consequences of grazing pressure for community diversity. - Biological Conservation 81: 275-286.

Gimingham, C. H. 1985: Age-related interactions between Calluna vulgaris and phytophagous insects. - Oikos 44: $12-16$.

Grandchamp, A. C., Bergamini, A., Stofer, S., Niemelä, J., Duelli, P. \& Scheidegger, C. 2005: The influence of grassland management on ground beetles (Carabidae, Coleoptera) in Swiss montante meadows. - Agriculture, Ecosystems and Environment 110: 307-317.

Gutiérrez, D. \& Menéndez, R. 1997: Patterns in the distribution, abundance and body size of carabid beetles (Coleoptera: Caraboidea) in relation to dispersal ability. - Journal of Biogeography 24: 903-914.

Gutiérrez, D., Menéndez, R. \& Méndez, M. 2004: Habitatbased conservation priorities for carabid beetles within the Picos de Europa National Park, northern Spain. - Biological Conservation 115: 379-393.

Haysom, K. A., McCracken, D. I., Foster, G. N. \& Sotherton, N. W. 2004: Developing grassland conservation headlands: response of carabid assemblage to different cutting regimes in a silage field edge. - Agriculture, Ecosystems and Environment 113: 51-61.

Ings, T. C. \& Hartley, S. E. 1999: The effect of habitat structure on carabid communities during the regeneration of a native Scottish forest. - Forest Ecology and Management 1999: 123-136.

Jeannel, R. 1941-1942: Coléoptères Carabiques. Faune de France, vol. 39 \& 40. - Lechevalier, Paris. 1173 pp.

Jongman, R. H. G., Ter Braak, C. J. F. \& Van Tongeren, O. F. R. 1995: Data Analysis in Community and Landscape Ecology. - Cambridge University Press, Cambridge. 299 pp.

Jukes, M. R., Peace, A. J. \& Ferris, R. 2001: Carabid beetle communities associated with coniferous plantations in Britain: the influence of site, ground vegetation and stand structure. - Forest Ecology and Management 148: 271-286.

Koivula, M. 2002: Boreal carabid-beetle (Coleoptera, Carabidae) assemblages in thinned uneven-aged and clear-cut spruce stands. - Annales Zoologici Fennici 39: 131-149.

Koivula, M., Kukkonen, J. \& Niemelä, J. 2002: Boreal carabid-beetle (Coleoptera, Carabidae) assemblages along the clear-cut originated succession gradient. Biodiversity and Conservation 11: 1269-1288.

Koivula, M., Kotze, D. J., Hiisivuori, L. \& Rita, H. 2003 : Pitfall trap efficiency: do trap size, collecting fluid and vegetation structure matter? - Entomologica Fennica 14:1-14.

Kirby, P. 1992: Habitat management for invertebrates. Royal Society for the Protection of Birds, Sandy.

Koricheva, J., Mulder, C. P. H., Schmid, B., Joshi, J. \& Huss-Danell, K. 2000: Numerical responses of different trophic groups of invertebrates to manipulations of plant diversity in grasslands. — Oecologia 125: 271282.

Latty, E. F., Werner, S. M., Mladenoff, D. J., Raffa, K. F. \& Sickley, T. A. 2006: Response of ground beetle (Carabidae) assemblages to logging history in northern hardwoodhelmlock forests. - Forest Ecology and Management 222: 335-347.

Lindroth, C. H. 1974: Coleoptera Carabidae. Handbooks for the Identification of British Insects. Vol. 4(2). Royal Entomological Society, London. 148 pp.

Luis-Calabuig, E., Tárrega, R., Calvo, L., Marcos, E. \& Valbuena, L., 2000: History of landscape changes in northwest Spain according to land use and management. - In: Trabaud, L. (ed.), Life and environment in Mediterranean Ecosystem: 43-86. Wit Press, Southampton, United Kingdom.

Marrs, R. H. 1993: An assessment of change in Calluna heathlands in Breckland, Eastern England, between 1983 and 1991. - Biological Conservation 65: 133139.

McFerran, D. M., McAdam, J. H. \& Montgomery, W. I. 1995: The impact of burning and grazing on heathland plants and invertebrates in County Antrim. - Biology and Environment 95B (1): 1-17.

Mohamed, B. F. \& Gimingham, C. H. 1970: The morphology of vegetative regeneration in Calluna vulgaris. New Phytologist (London) 69: 743-750.

Niemelä, J. 1993: Mystery of the missing species: speciesabundance distribution of boreal ground-beetles. Annales Zoologici Fennici 30: 169-172.

Ortuño, V. M. \& Marcos, J. M. 2003: Los Caraboidea (Insecta: Coleoptera) de la comunidad autónoma del País Vasco. Tomo I. - Servicio Central de Publicaciones del Gobierno Vasco, Spain. 573 pp. [In Spanish.]

Peláez, M. C. 2004: Estudio faunístico, ecológico y biogeográfico de los Carabidae (Coleoptera) del macizo del Sueve (Asturias, España). — PhD thesis, Universidad de León, Spain. 893 pp. [In Spanish.]

Pekár, S. 2002: Differential effects of formaldehyde concentration and detergent on the catching efficiency of surface active arthropods by pitfall traps. Pedobiologia 46: 539-547.

Penas, A., García, M. E. \& Herrero, L. 1995: Series de vegetación. Atlas del medio natural de la provincia de León. - Instituto Tecnológico Geominero de España y Diputación de León, Spain. 104 pp. [In Spanish.]

Pihlaja, M., Koivula, M. \& Niemelä, J. 2006: Responses of boreal carabid beetles assemblages (Coleoptera, Carabidae) to clear-cutting and top-soil preparation. — Forest Ecology and Management 222: 182-190.

Pitcairn, C. E. R. \& Fowler, D. 1995: Deposition of fixed atmospheric nitrogen and foliar nitrogen content of bryophytes and Calluna vulgaris (L.) Hull. - Environmental Pollution 88: 193-205.

Purtauf, T., Dauber, J. \& Wolters, V. 2004: Carabid communities in the spatio-temporal mosaic of a rural landscape. - Landscape and Urban Planning 67: 185193.

R Development Core Team 2005: R: A language and envi- 
ronment for statistical computing. - R Foundation for Statistical Computing, Vienna, Austria. ISBN 3900051-07-0, URL http:/www.R-project.org

Rainio, J. \& Niemelä, J. 2003: Ground beetles (Coleoptera: Carabidae) as bioindicators. - Biodiversity and Conservation 12: 487-506.

Raworth, D. A. \& Choi, M. Y. 2001: Determining numbers of active carabid beetles per unit area from pitfall-trap data. - Entomologia Experimentalis et Applicata 98: 95-108.

Rivas-Martínez, S., Gandullo, J. M., Allue, J. L., Montero, J. L. \& González, J. L. 1987: Memoria del mapa de series de vegetación de España. — ICONA, Madrid. [In Spanish.]

Serrano, J. 2003: Catálogo de los Carabidae (Coleoptera) de la Península Ibérica. - Monografías de la Sociedad Entomológica Aragonesa Vol. 9, Zaragoza, Spain. 130 pp. [In Spanish.]

Shannon, C. E. \& Weaver, W. 1949: The mathematical theory of communication. - Univ. Illinois Press, Urbana. $117 \mathrm{pp}$.

Taboada, A., Kotze, D. J. \& Salgado, J. M. 2004: Carabid beetle occurrence at the edges of oak and beech forests in NW Spain. - European Journal of Entomology 101: 555-563.

Taboada, A., Kotze, D. J., Salgado, J. M. \& Tárrega, R. 2006: The influence of habitat type on the distribution of carabid beetles in traditionally managed dehesa ecosystems in NW Spain. - Entomologica Fennica 17: 284-295.

Telfer, M. G. \& Eversham, B. C. 1996: Ecology and conservation of heathland Carabidae in eastern England. Annales Zoologici Fennici 33: 133-138.

Ter Braak, C. J. F. 1987: CANOCO - a fortran Program for Canonical Community Ordination (version 4). - Microcomputer Power, Ithaca, New York, USA.

Ter Braak, C. J. F. \& Smilauer, P. 1998: CANOCO Reference Manual and User's Guide to CANOCO for Windows: Software for Canonical Community Ordination (version 4). - Microcomputer Power, New York, USA.

Thomas, C. F. G., Parkinson, L. \& Marshall, E. J. P. 1998: Isolating the components of activity-density for the carabid beetle Pterostichus melanarius in farmland. - Oecologia 116: 103-112.

Thomas, C. F. G., Brown, N. J. \& Kendall, D. A. 2006: Carabid movement and vegetation density: Implica- tions for interpreting pitfall trap data from split-field trials. - Agriculture, Ecosystems and Environment 113: 51-61.

Trautner, J. \& Geigenmüller, K. 1987: Tiger Beetles, Ground Beetles: Illustrated Key to the Cicindelidae and Carabidae of Europe. - Margraf, Germany. 488 pp.

Tutin, T. G., Heywood, V. H., Burges, N. A., Valentine, D. H., Moore, D. M., Walters, S. M. \& Webb, D. A. 1964 1980: Flora Europea. — Cambridge University Press, Cambridge.

Usher, M. B. 1992: Management and diversity of arthropods in Calluna heathland. - Biodiversity and Conservation 1: 63-79.

Usher, M. B. \& Thompson, D. B. A. 1993: Variation in the upland heathlands of Great Britain: Conservation importance. - Biological Conservation 66: 69-81.

Van Essen, S. J. 1994: A method to evaluate the condition of heathlands by using catches of carabid beetles. In: Desender, K. et al. (Eds.), Carabid beetles: Ecology and Evolution: 383-386. Kluwer Academic Publishers.

Vanbergen, A. J., Woodcock, B. A., Watt, A. D. \& Niemelä, J. 2005: Effect of land-use heterogeneity on carabid communities at the landscape scale. - Ecography 28: 3-16.

Vázquez, M. G. 1990: Estudio faunístico, biogeográfico y ecológico de los Caraboidea (Coleoptera) entre las cuencas de los ríos Bernesga, Torío y Porma (León, España). - PhD thesis, Universidad de León, Spain. 455 pp. [In Spanish.]

Watt, A. S. 1955: Bracken versus heather, a study in plant sociology. - Journal of Ecology 43: 490-506.

Webb, N. R. 1986: Heathlands. - Collins, London.

Webb, N. R. 1998: The traditional management of European heathlands. - Journal of Applied Ecology 35: 987-990.

Webb, N. R. \& Hopkins, P. J. 1984: Invertebrate diversity on fragmented Calluna heathland. - Journal of Applied Ecology 21: 921-933.

Webb, N. R., Clarke, R. T. \& Nicholas, J. T. 1984: Invertebrate diversity on fragmented Calluna-heathland: Effects of surrounding vegetation. - Journal of Biogeography 11: 41-46.

Woodcock, B. A. 2005: Pitfall trapping in ecological studies. - In: Leather, S. (ed.), Insect Sampling in Forest Ecosystems: 37-57. Blackwell Science Ltd. 